\title{
WYKORZYSTANIE WIRTUALNEJ RZECZYWISTOŚCI W ZARZĄDZANIU
}

\author{
Stanisław Sośniak \\ Politechnika Częstochowska \\ Wydział Zarządzania
}

\begin{abstract}
Streszczenie: Technologia wirtualnej rzeczywistości przyczyniła się do powstania nowych możliwości rozwoju społeczeństwa oraz udostępniła zupełnie nowe i bardziej doskonałe narzędzia wspomagające zarządzanie. Celem artykułu jest próba udzielenia odpowiedzi na pytania dotyczące wykorzystania nowoczesnych technologii w zarządzaniu i ich wpływu na zachowania konsumentów. W tym celu uwzględniono wybrane aktualne źródła literaturowe, przedstawiono graficzną interpretację oraz analizę dotyczącą częstości wyszukiwania hasła „virtual reality” w wyszukiwarce internetowej Google. Ponadto szczególnie zwrócono uwagę na relacje między procesem zarządzania a wybranymi przykładami narzędzi i technik zarządzania wirtualną rzeczywistością, które obecnie dominują na rynku i są wykorzystywane przez największe organizacje.
\end{abstract}

Słowa kluczowe: zarządzanie, nowoczesna technologia, wirtualna rzeczywistość

DOI: $10.17512 /$ znpcz.2018.1.11

\section{Wprowadzenie}

Współczesny konsument funkcjonuje w dobie digitalizacji oraz technologii mobilnej, przepełnionej komunikatami marketingowymi w różnych formach, m.in. przez Internet, sieci komórkowe, media, radio, telewizję (Kotler, Keller 2013, s. 13-15). Rozwój technologii informacyjnej na przełomie XX i XXI wieku, dzięki wykorzystaniu narzędzi teleinformatycznych oraz światowej komunikacji cyfrowej, pozwolił z dużą łatwością pozyskiwać i przetwarzać informacje. Zmiany te odczuwalne są we wszystkich dziedzinach życia społeczno-gospodarczego, przyczyniły się do powstania nowych zjawisk i procesów, a także metod zarządzania. $\mathrm{W}$ organizacjach presja wywierana przez konkurencję przyczyniła się m.in. do poprawy efektywności procesów zarządzania, skuteczności procesów decyzyjnych oraz jakości w organizacjach i instytucjach (Kiełtyka 2017b, s. 34-36).

Technologia wirtualnej rzeczywistości wywołała rewolucyjne zmiany w naszym świecie, porównywalne tylko z odkryciem koła, elektryczności czy druku. Spowodowała powstanie największego rynku w dziejach cywilizacji, czyli tzw. e-rynku. Jest to niewątpliwie technologia, która używana jest bardzo często do wytwarzania rzeczywistych bądź też wirtualnych produktów i usług. Posługuje się zupełnie odmiennymi niż technologia tradycyjna narzędziami, takimi jak: maszyny wirtualne, modelowanie czy też symulacja (Kisielnicki 2012, s. 3). 
Charakterystyczną cechą współczesnej cywilizacji jest postęp nowych technologii. Żyjemy w czasach nieustającego rozwoju Internetu. Na co dzień wykorzystywane są różnego rodzaju aplikacje, np. Facebook czy YouTube, spotyka się wszechobecną wirtualną rzeczywistość i inne zaawansowane technologie. Technologia wirtualnej rzeczywistości przyczyniła się do powstania nowych możliwości rozwoju społeczeństwa, udostępniła zupełnie nowe i bardziej doskonałe narzędzia wspomagające zarządzanie. Ma też swój znaczący udział w transformacji społeczeństwa przemysłowego w społeczeństwo informacyjne, oparte na zarządzaniu wiedza.

Celem artykułu jest próba udzielenia odpowiedzi na pytania dotyczące wykorzystania nowoczesnych technologii $\mathrm{w}$ zarządzaniu i ich wpływu na zachowania konsumentów. W tym celu uwzględniono wybrane aktualne źródła literaturowe, przedstawiono graficzną interpretację oraz analizę dotyczącą częstości wyszukiwania haseł związanych z wirtualną rzeczywistością „,virtual reality” w wyszukiwarce internetowej Google. Ponadto szczególnie zwrócono uwagę na relacje między procesem zarządzania a wybranymi przykładami narzędzi i technik zarządzania wirtualną rzeczywistością, które obecnie dominują na rynku i są wykorzystywane przez największe organizacje.

\section{Istota wirtualnej rzeczywistości}

Wirtualna rzeczywistość, określana w języku angielskim jako virtual reality (VR), wykorzystuje możliwości technologii informacyjnej i stanowi potencjał w różnych obszarach życia człowieka. Stosuje technologie trójwymiarowego środowiska, pozwalające użytkownikowi na poruszanie się w wirtualnej przestrzeni, a także interakcję, której rezultatem jest pobudzenie co najmniej jednego ze zmysłów człowieka. Wirtualna rzeczywistość postrzegana jest jednocześnie jako nierzeczywista i rzeczywista. Nierzeczywista, gdyż użytkownik jest świadom uczestnictwa w świecie wirtualnym, będącym zamiennikiem prawdziwego. Rzeczywista, ponieważ relacja i stopień interakcji wydają się zbliżone $\mathrm{z}$ doświadczeniami w prawdziwym życiu. Głównym problemem tworzenia wirtualnej rzeczywistości jest konieczność dokładnego odwzorowania i próba stworzenia systemu z minimalnym opóźnieniem ruchów użytkownika (Guttentag 2010, s. 637-651).

Technologia wirtualnej rzeczywistości to obraz rzeczywistości sztucznej, utworzonej przy użyciu technologii informatycznych, oparty na multimedialnym kreowaniu obrazu świata realnego lub fikcyjnego, przedmiotów, zdarzeń lub przestrzeni. Charakterystyczną cechą współczesnego życia człowieka jest coraz większa liczba czynności do odzwierciedlenia w wirtualnej rzeczywistości, które zastępują po części lub w całości realne procesy (Kęsy 2014, s. 42-47).

Wirtualna rzeczywistość oprócz możliwości wykorzystywania jej przez użytkowników prywatnych daje rozwiązania wspierające przemysł rozrywkowy, medyczny i wojskowy, a także procesy produkcyjne, wykorzystując narzędzia wspomagające sprzedaż czy projektowanie oraz specjalistyczne aplikacje szkoleniowe. Wirtualna rzeczywistość to system podzielony na sprzęt i oprogramowanie, które wspólnie zapewniają użytkownikowi wysoki stopień immersji. Głównym zmysłem 
wykorzystywanym w wirtualnej rzeczywistości jest wzrok, któremu przekazywane są wirtualne informacje, a osiągnięcie tego jest możliwe za pomocą sygnałów pochodzących z prawdziwego świata.

Podstawowym komponentem systemu wirtualnej rzeczywistości jest aplikacja określana jako zamknięty program zawierający wirtualne modele obiektów znajdujących się w środowisku zapewniającym immersje oraz interakcję dla użytkownika. Inżynierskie aplikacje wirtualnej rzeczywistości przedstawiają symulacje działania wirtualnego stanowiska, konfiguratora produktów, obsługi montażu i demontażu oraz wykorzystywane są do szkolenia personelu, celów marketingowych, wizualizacji produktów oraz funkcjonalności (Zawadzki i in. 2016, s. 256-257).

\section{Wykorzystanie wirtualnej rzeczywistości w zarządzaniu}

Tradycyjne zarządzanie staje się dysfunkcjonalne, ponieważ nie posiada wiedzy na tematy technologiczne, kapitału intelektualnego, rosnącej siły klientów, globalizacji, wirtualności wykorzystywanych mediów. Organizacja, chcąc być liderem na rynku, musi korzystać z nowoczesnych technologii informatycznych. Szczególną uwagę należy zwrócić na poziom innowacyjności technologii, jej determinanty, źródła i bariery. Znaczącą rolę odgrywa motywacja i zdolność do poszukiwania i wykorzystania nowych koncepcji, wyników badań naukowych, wynalazków, pomysłów, nowatorskich opracowań organizacyjnych. Organizacja wprowadzająca innowacje jest zależna od zatrudnionych pracowników o odpowiednim potencjale, wiedzy i zdolności twórczej. Wprowadzanie innowacyjności wzmacnia motywację, metody partycypacyjne w rozwiązywaniu problemów i technikach zarządzania (Kiełtyka 2017a, s. 32-34).

W przedsiębiorstwie nowi pracownicy mogą otrzymać zestaw materiałów zawierających informacje o procedurach, osiągnięciach, celach, misji zrównoważonego rozwoju w przedsiębiorstwie. Innowacyjne zarządzanie motywacją pracowników jest podstawową funkcją zarządzania, która odgrywa trudną i złożoną rolę (Pabian 2015, s. 11-12).

Innowacje często powstają dzięki skrzyżowaniu różnych dyscyplin, wiążąc ze sobą różne dziedziny, pomysły i problemy, choć według niektórych innowatorów nie ma pomiędzy nimi żadnego związku. Implementacja innowacyjnych idei zarządczych jest skierowana na rozwój przedsiębiorstw i organizacji otwartych na kontakt z liderami branżowymi, koncentrującymi się na ważnych i potrzebnych innowacjach, które posiadają większe możliwości przysparzania korzyści niż ryzyka (Szkutnik 2016, s. 235-241).

Charakterystyczną cechą współczesnego człowieka jest zastępowanie części procesów realnych procesami w wirtualnej rzeczywistości. Możliwości technologii informacyjnej pozwalają wykorzystać istniejące rozwiązania w różnych obszarach życia człowieka. Przykładem zastosowania wirtualnej rzeczywistości jest proces kształcenia na symulatorze wirtualnej rzeczywistości, który jest jednym z najlepszych sposobów pozyskiwania umiejętności oraz ich dalszej weryfikacji. Połączenie elementów rzeczywistych $\mathrm{z}$ efektem zanurzenia $\mathrm{w}$ wirtualnym środowisku powoduje poczucie realizmu, nie pociągając z sobą ryzyka negatywnych kon- 
sekwencji pomyłek, jakie występują podczas tradycyjnego szkolenia (Kęsy 2016, s. 125-127).

Wysoki poziom środowiska wirtualnego w symulacji szkoleniowej związany jest z zaangażowaniem wzroku i słuchu, ale również innych zmysłów. Efektywność szkolenia zwiększa zaangażowanie pamięci mięśniowej, osoba wykonująca podobne zadania $\mathrm{w}$ pracy $\mathrm{w}$ środowisku wirtualnym szybciej zdobędzie kompetencję i wiedzę. Realizm symulacji jest związany z dokładnym odtworzeniem rzeczywistego miejsca, dodatkowo zmniejszenie liczby abstrakcyjnych pojęć jest przydatne w kontekście szkolenia starszych osób i funkcjonowania poznawczego. Przeprowadzone badania wskazują, że osoby starsze posiadające $\mathrm{z}$ wiekiem kłopoty z funkcjami poznawczymi, dobrze radzą sobie z realistycznymi sytuacjami, a takie warunki zapewnia technologia wirtualnej rzeczywistości (Grabowski, Myśliwiec 2016, s. 690-691).

Dzięki nowym rozwiązaniom technicznym możliwe jest wykorzystanie wirtualnej rzeczywistości w edukacji akademickiej, umożliwiające budowanie nowych relacji pomiędzy nauczycielem a studentem. Uczestnik w wirtualnym świecie może brać udział jak uczestnik spektaklu teatralnego, a nie być biernym odbiorcą. Wykorzystanie wirtualnej rzeczywistości w procesie kształcenia daje możliwość intensywnego, aktywnego uczestnictwa w zajęciach, pozwala współtworzyć akcję i reakcję z obiektami w wirtualnym środowisku (Topola i in. 2017, s. 206-207).

Naukowcy z Holandii opracowali np. oprogramowanie The Virtual Supermarket - wirtualny supermarket przedstawiony w postaci trójwymiarowej aplikacji, w którym klienci mogą robić zakupy w zbliżony sposób do rzeczywistego supermarketu. Wirtualny supermarket posiada front dostępny dla klientów oraz tył umożliwiający przeprowadzenie badania przez prowadzącego. Aplikacja zbiera dane o wielkości wydatków, zakupionych produktach, czasie spędzonym na zakupach. Dane są gromadzone i dostępne na serwerze prowadzącego badanie. Wirtualna rzeczywistość pozwala zrozumieć i poznać zachowania rynkowe oraz prowadzić badania na konsumentach, a w końcowym rezultacie przygotować produkt do oczekiwań klienta (Berbeka 2016, s. 94-96).

Nieustannie trwają prace nad szerszym zastosowaniem wirtualnej rzeczywistości w turystyce, dzięki której turysta będzie miał możliwość odbycia wirtualnego spaceru po wybranych obiektach turystycznych bez konieczności wychodzenia $\mathrm{z}$ domu. Wśród jednostek korzystających z technologii wirtualnej rzeczywistości znajdują się m.in. kościoły i muzea przedstawiające architekturę czy dzieła sztuki, umożliwiające turystom wirtualny spacer przy wykorzystaniu zdjęć oraz filmów, bez wychodzenia $\mathrm{z}$ domu. Jest to jedna $\mathrm{z}$ form promocji, zachęcająca turystów do odwiedzenia interesującego miejsca, które wcześniej może zobaczyć w wirtualnej rzeczywistości (Krysiak, Głowania 2017, s. 98-101).

Zastosowanie technologii wirtualnej rzeczywiści stanowić będzie nowy krok w opisywanych przedsięwzięciach. Przyszłością organizacji jest wzmocnienie konkurencyjności na rynku, szersza i bardziej dostępna oferta, obniżenie kosztów wdrażania i promocji zastosowana poprzez przeniesienie procesów organizacji do przestrzeni wirtualnej oraz rozszerzenie narzędzi komunikacji elektronicznej o wirtualną rzeczywistość. 


\section{Analiza wirtualnej rzeczywistości według statystyk Google}

Analiza danych statystycznych Google dotycząca popularności wirtualnej rzeczywistości od 2013 do 2018 roku z wyszczególnieniem wszystkich obszarów świata przedstawiona została na Rysunku 1 .

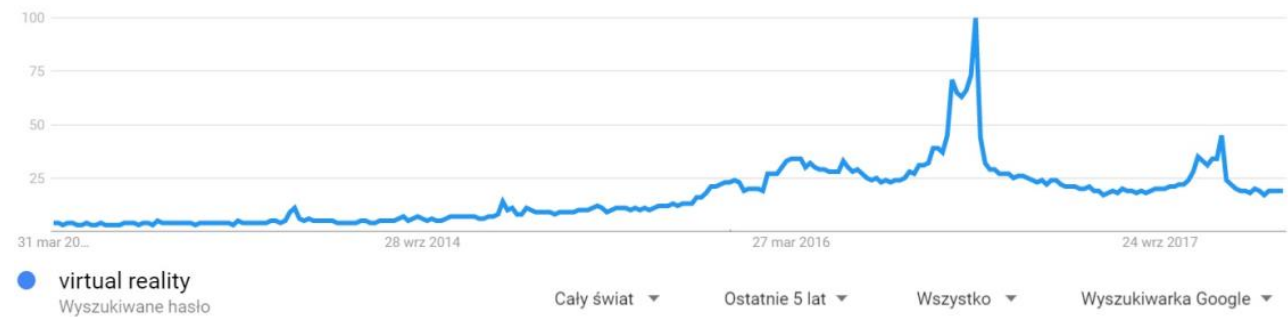

Rysunek 1. Wirtualna rzeczywistość - popularność według statystyk Google

Źródło: (https://trends.google.com/...)

Analizując powyższy rysunek, należy zauważyć, iż pierwszy znaczący wzrost popularności wirtualnej rzeczywistości nastąpił w marcu 2014 roku. W tym okresie Facebook zakupił za 2 mld dolarów firmę Oculus VR produkującą okulary do wirtualnej rzeczywistości. Jednocześnie współzałożyciel Facebooka Mark Zuckerberg stwierdził, iż wirtualna rzeczywistość może być kierunkiem wykorzystywania technologii w przyszłości, pozwalając zobaczyć budowlę modelu oddaloną o wiele kilometrów (https://www.nytimes.com/...).

Dane przedstawione na Rysunku 1 pozwalają zauważyć, że kolejny znaczący wzrost zainteresowania tematyką wirtualnej rzeczywistości nastąpił w 2015 roku. Bez wątpienia miało to związek z przedsięwzięciem podjętym przez firmę Thomas Cook, będąca pionierem w turystyce. Firma ta zleciła wykonanie serii filmów w wirtualnej rzeczywistości „Try Before You Fly” dla potencjalnych klientów z Niemiec, Belgii i Wielkiej Brytanii, które wykorzystując technologię wirtualnej rzeczywistości przy pomocy urządzeń Samsung Gear VR, przedstawiały miejsca, do których turyści chcieliby polecieć. Filmy przedstawiają Egipt, Grecję, Cypr, Singapur i Nowy Jork, a zindywidualizowane treści zawierające miejsca oferowane przez firmę Thomas Cook pozwalały klientom cieszyć się takimi wycieczkami, jak: przelot helikopterem po Manhattanie, pobyt w basenie na Rodos, zwiedzanie egipskich piramid oraz spacer po Skyway w Singapurze (http://visualise.com/...).

Największa popularność haseł związanych $\mathrm{z}$ wirtualną rzeczywistością według wyszukiwarki Google przypada na 2017 rok. W okresie tym większość urządzeń telefonicznych - smartfonów była w stanie wyświetlić film przy wykorzystaniu prostych do zamontowania i łatwo dostępnych gogli do smartfona oraz markowych gogli Samsung Gear VR, Sony VR, Oculus Rift VR itp.

Analiza Rysunku 1 pozwala wskazać również na regularne wzrosty dotyczące ilości wyszukiwań w Google haseł dotyczących wirtualnej rzeczywistości głównie w okresach świąt Bożego Narodzenia i Wielkiej Nocy oraz podczas sezonu wakacyjnego. Wynikać to może ze wzmożonej w okresie świąt promocji urządzeń do 
demonstrowania wirtualnej rzeczywistości, a w okresie letnim - z potrzeby obejrzenia wizualizacji miejsc planowanego pobytu.

Na kolejnym rysunku (Rysunek 2), będącym odzwierciedleniem danych Google, zaprezentowano stopień popularności technologii wirtualnej rzeczywistości według regionów świata.

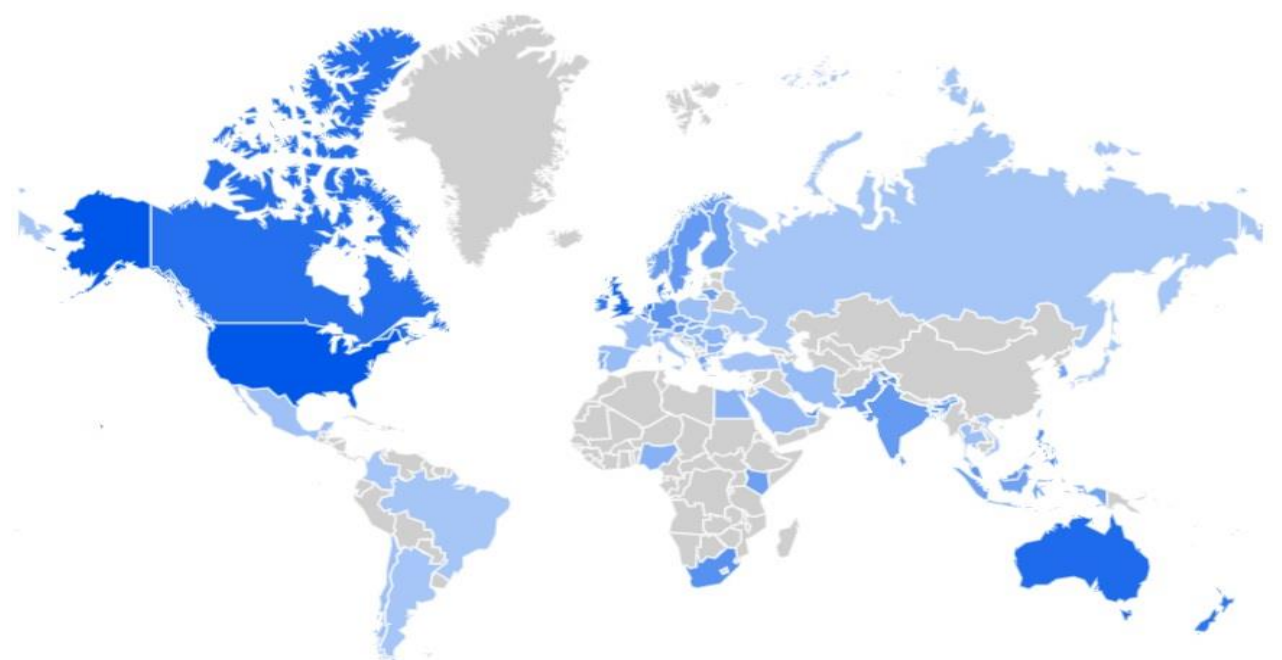

Rysunek 2. Popularność wirtualnej rzeczywistości według statystyk Google

Źródło: (https://trends.google.com/...)

Miejsca oznaczone na powyższym rysunku kolorem szarym przedstawiają regiony, w których Google nie odnotował danych dotyczących ilości wyszukiwań w wyszukiwarce Google tematyki dotyczącej wirtualnej rzeczywistości. W przypadku regionów podlegających badaniu w kierunku ilości haseł związanych z wirtualną rzeczywistością zastosowano tonacje koloru niebieskiego. Kolorem ciemnoniebieskim oznaczono kraje, gdzie hasło „wirtualna rzeczywistość” wyszukiwane jest najczęściej, a najjaśniejszy kolor niebieski oznacza najmniejsze zainteresowanie tą tematyką. Na podstawie Rysunku 2 można stwierdzić, że wirtualna rzeczywistość jest najpopularniejsza w Stanach Zjednoczonych, Holandii, Wielkiej Brytanii, Australii i Kanadzie. Polska znajduje się na 48. miejscu wśród 60 regionów.

Analiza danych według podziału na kraje pozwala przedstawić najbardziej aktywnych użytkowników, do których możemy skierować np. ofertę promocyjną.

\section{Podsumowanie}

W czasach rozwiniętej technologii organizacje pokonują ograniczenia menedżerów, kierowników i pracowników, odrzucają standardowy model zarządzania i stosując nowoczesne modele zarządzania, wykorzystują najnowsze zaawansowane technologie, które skracają czas i zmniejszają koszty poniesione przez organizacje. 
Technologia wirtualnej rzeczywistości w zarządzaniu:

- Zastępuje część procesów realnych procesami w wirtualnej rzeczywistości.

- Udostępnia nowe narzędzia wspomagania zarządzania.

- Wdraża innowacyjne rozwiązania w celu zwiększenia potencjału, wiedzy i zdolności twórczej pracowników.

- Wprowadza metody partycypacyjne w rozwiązaniu problemów i technikach zarządzania.

Najnowsze technologie teleinformatyczne w połączeniu z kreatywnością ludzi pozwalają wydajnie wykorzystać dotychczas zdobyte informacje i osiągnięcia. Wirtualna rzeczywistość ogarnęła niemalże wszystkie dziedziny życia, a jej znaczenie rośnie $\mathrm{z}$ roku na rok. Wirtualna rzeczywistość posiada przewagę w porównaniu z innymi formami komunikacji z rynkiem, w połączeniu z przekazem promocyjnym jest nieszablonowa $\mathrm{w}$ podejściu do relacji z klientem oraz posiada swoje miejsce w dziedzinie spędzania czasu wolnego. Doskonałym przykładem są gry komputerowe, gdzie użytkownik przenosi się do sztucznie stworzonego środowiska na zupełnie nowym poziomie doznań. Ta nowatorska technika tworzenia obrazu sztucznej rzeczywistości przy wykorzystaniu technologii informatycznej wykorzystywana jest również $\mathrm{z}$ powodzeniem w przedsiębiorstwach, gdzie zapewnia łatwy i przystępny sposób przekazywania i przyswajania informacji. Powoduje również redukcję kosztów podróży, możliwość szybkiego dotarcia do pracowników oraz spadek ilości spędzonego czasu w delegacjach służbowych.

Według autora dzięki wykorzystaniu wirtualnej rzeczywistości w zarządzaniu organizacje, instytucje i przedsiębiorstwa mogą optymalizować procesy i skuteczność funkcjonowania. Ograniczenia dokonanej analizy wynikają z niemożności ujęcia w niniejszym artykule rozległej specjalistycznej wiedzy projektantów i programistów innowacyjnych aplikacji wirtualnej rzeczywistości oraz braku możliwości zademonstrowania potencjału tej technologii. Problemy te mogą być tymczasowe, ponieważ rozwój i innowacyjność technologii umożliwia niwelowanie opisanych barier. Internet, analityka predyktywna, wirtualna rzeczywistość będą wkraczać w nasze życie, a ich wykorzystanie jest tylko ograniczone skalą wyobraźni. Nie można przy tym zapomnieć o niebezpieczeństwach, jakie niesie Internet, gromadzenie danych osobowych w rękach instytucji, rządów i firm.

\section{Literatura}

1. Berbeka J. (2016), Wirtualna i rozszerzona rzeczywistość a zachowania konsumentów, „Studia Ekonomiczne. Zeszyty Naukowe Uniwersytetu Ekonomicznego w Katowicach”, nr 303, s. 84-101.

2. Grabowski A., Myśliwiec M. (2016), Rzeczywisty i wirtualny symulator uproszczonego stanowiska pracy przeznaczony do badań funkcjonowania poznawczego, „Mechanik”, R. 89, nr 7, s. 690-691. DOI: 10.17814/mechanik.2016.7.128

3. Guttentag D.A. (2010), Virtual Reality: Applications and Implications for Tourism, „Tourism Management”, Vol. 31(5), s. 637-651. DOI: 10.1016/j.tourman.2009.07.003

4. http://visualise.com/case-study/thomas-cook-virtual-holiday (dostęp: 10.04.2017).

5. https://trends.google.com/trends/explore?date=today\%205-y\&q=virtual\%20reality (dostęp: 07.04.2017) 
6. https://www.nytimes.com/2014/03/26/technology/facebook-to-buy-oculus-vr-maker-ofvirtual-reality-headset.html (dostęp: 10.04.2017).

7. Kęsy M. (2014), Rzeczywistość wirtualna w procesie ksztatcenia technicznego, „Edukacja Technika - Informatyka", nr 5(1), s. 42-47.

8. Kęsy M. (2016), Symulatory wirtualnej rzeczywistości, „Dydaktyka Informatyki”, nr 11, s. 125-131. DOI: $10.15584 /$ di.2016.11.16

9. Kieltyka L. (2017a), Inspiracje i innowacyjność w zarzqdzaniu wspótczesnymi organizacjami. Wykorzystanie nowoczesnych technologii w tworzeniu innowacyjnych strategii organizacji, ,Przegląd Organizacji”, nr 7, s. 32-37.

10. Kiełtyka L. (2017b), Narzędzia i technologie multimedialne wspomagajace pracę menedżerów we wspótczesnych organizacjach, „Przegląd Organizacji”, nr 8, s. 33-42.

11. Kisielnicki J. (2012), Rozwój technologii informatycznych. Technologie wirtualne jako narzędzia wspomagajace zarzadzanie, Uniwersytet Warszawski, Warszawa.

12. Kotler P., Keller K.L. (2013), Marketing, Dom Wydawniczy Rebis, Poznań.

13. Krysiak M., Głowania S. (2017), Wplyw zastosowań nowoczesnych technologii na atrakcyjność i popularność muzeów w Polsce, „Prace Naukowe Uniwersytetu Ekonomicznego w Katowicach”: Biznes w kulturze - kultura w biznesie: nowoczesne technologie informacyjno-komunikacyjne, s. 96-107.

14. Pabian A. (2015), Zrównoważone zarzadzanie zasobami ludzkimi - zarys problematyki, „Zeszyty Naukowe Politechniki Częstochowskiej. Zarządzanie”, nr 17, s. 7-16.

15. Szkutnik J. (2016), Wielowymiarowy aspekt innowacyjności w działalności spolecznej i gospodarczej. Horyzonty wspótczesnego zarzadzania, Wydawnictwo Naukowe Wydziału Zarządzania Uniwersytetu Warszawskiego, Warszawa.

16. Topola P., Kołodziejczak B., Roszak M., Dutkiewicz A., Zych J., Januszewski M., Bręborowicz A. (2017), Światy wirtualne 3D w edukacji akademickiej, Wydawnictwo Uniwersytetu Rzeszowskiego, Rzeszów.

17. Zawadzki P., Górski F., Buń P., Hamrol A., Kuczko W., Wichniarek R. (2016), Wspomaganie projektowania koncepcyjnego mebli z zastosowaniem aplikacji rzeczywistości wirtualnej $i$ technik opartych na wiedzy, [w:] Knosala R. (red.), Innowacje w zarzadzaniu i inżynierii produkcji, t. 1, Oficyna Wydawnicza Polskiego Towarzystwa Zarządzania Produkcją, Opole, s. 256-266.

\title{
USE OF VIRTUAL REALITY IN MANAGEMENT
}

\begin{abstract}
Virtual reality technology has contributed to the creation of new opportunities for the development of society and has made available completely new and better management support tools. The article is an attempt to answer questions regarding the use of modern technologies in management and their impact on consumer behavior. To this end, the article provides an overview of recent research in this field, a graphical interpretation and frequency search analysis for "virtual reality" in Google search engine. In addition, the article focuses on the relationships between the management process and selected examples of virtual reality management tools and techniques that currently dominate the market and are used by larger organizations.
\end{abstract}

Keywords: management, modern technology, virtual reality 